\title{
Effects of Eight Week Plyometric Study on the Balance Performance of Hearing Impaired Athletes
}

\author{
Ersin Nacaroglu ${ }^{1} \&$ Onder Karakoc ${ }^{1}$ \\ ${ }^{1}$ Department of Physical Education and Sports, Gaziantep University, Gaziantep, Turkey \\ Correspondence: Onder Karakoc, Department of Physical Education and Sports, Gaziantep University, Gaziantep, \\ Turkey. E-mail: onderkarakoc@hotmail.com
}

Received: February 19, 2018

Accepted: March 22, 2018 Online Published: May 8, 2018

doi:10.5539/ies.v11n6p1

URL: https://doi.org/10.5539/ies.v11n6p1

\begin{abstract}
This is an experimental study and it was aimed to identify the effects of 8-week plyometric training of hearing-impaired athletes on balance. 24 Male hearing-impaired volleyball players participated in the study. Random method was used when experimental and control groups were identified. Subjects used in the study were divided into two groups as experiment $(12$ male age $=19.08 \pm 1.62)$ and control group (12 male age $=17.75 \pm$ 1.28). 3 days $/ 90$ min. volleyball training programme was applied for two groups per week.

For the experimental group, plyometric training was applied after warming before the volleyball training sessions. The control group continued their regular volleyball training. Statistical results were evaluated at $95 \%$ confidence interval and $\mathrm{p}<0.05$ significance level. Because the pre-test and post-test measurements of the groups were normal and homogeneous distribution, the Paired Samples T-Test was applied for the significance between them. To analyze the differences between the experimental group and control group, Independent Samples T-test was used.

As a result of the plyometric exercises, the mean values of the pre-test and post-test differences of the static balance measurement parameters for the experimental and control groups were found to be significant in the values of overall stability $R$, medial lateral $R$, and overall stability $L$ values $(p<0.05)$. But, in the mean values, there was no significance of anterior posterior R., anterior posterior L. and medial lateral L. mean ( $p>0.05)$.

Consequently, it can be said that plyometric exercises have a positive effect especially on static balances of hearing-impaired volleyball players.
\end{abstract}

Keywords: volleyball, plyometric, training, balance, performance

\section{Introduction}

Prevention of hearing impairment is very important, while important developments are being made in the training of hearing-impaired individuals.

The most important problem with hearing impaired people is the functional failure of balance centers that work in coordination with each other because they cannot perceive external stimuli as auditory stimuli.

The absence of vestibular system functions causes the balance in dynamic and static situations influenced totally negatively even if the proprioceptors, visual perceptions and anti-gravity muscles work well. For those who suffer from hearing loss afterwards due to any reason, there is a disturbance of vestibular system dysfunction in the connections between balance structures because they only perceive external auditory stimuli for a short time. In normal development, all of these mentioned systems show a good improvement. When the sports habits of the hearing-impaired groups who do sports and do not to sports are examined in many studies, it is found that there are significant results in hearing impaired people who do sports from two groups, which are added to the program in the periodical balance tests. It has been identified that sporting activities contribute to the development of physical performances and balance skills of children with hearing impairment. It is quite common in the literature that sporting skills enhance the ability to work in coordinated, especially among vestibular coordination structures (Butterfield, 1991).

Mobility is based on standing upright. The fact that the work done in normal life can be done in a controlled and smooth way is explained by the relation between mobility and balance. Functional independence of persons depends on the healthy functioning of all body segments. It is known that in this framework, the healthcare team 
responsible for the rehabilitation of hearing-impaired individuals must thoroughly examine and evaluate the balance systems in ordinary practice and the ways to improve balance skills should be added to the rehabilitation programs (Yağc1 et al., 2004).

The control, suitability and smoothness characteristics between the movements of the skeletal-muscular system are called the 'coordination'. Coordination control involves extrapyramidal routes, the cerebellar posterior cord communication system, vestibular nuclei. There is a positive relationship between balance and coordination. Coordination is a complex and smooth movement process that is produced as a result of the working of the muscles together with timing and approximate width. For the development of coordination skills, the repetition of exercise and the continuity of performance have an important role (Riemann \& Lephart, 2002).

Hinman calls the balance as the center of gravity protection skill. Balance is also defined as rapid and postural adaptation to changes in the center of gravity during activity and rest. This adaptation is formed by combining proprioceptive, vestibular and visual information in the central nervous system (Sandrey, 2006).

Having a good strength training background allows the plyometric training efficiency to develop more effectively and quickly. Introducing athletes to plyometric exercise is quite effective in developing good strength-based and vibration-absorbing essential features. When this basis is established, the continuity of the exercises and the level of development of the athletes must be considered. Light intensity plyometric exercises may be performed during the first years of the individual's healthy training process. However, after this process, they must continue to work with the jump in challenging levels. Teaching of plyometric studies is of increasing importance (Bompa, 2001).

This is an experimental study and it was aimed to identify the effects of eight week plyometric training on balance and coordination of hearing impaired volleyball players. By including hearing-impaired volleyball players in this study, it was one of the perspectives of the study that distinguished it from other studies on plyometric training.

\section{Method}

\subsection{Experimental Method}

This is an experimental study and it was aimed to identify the effects of eight week plyometric training on balance and coordination of hearing-impaired athletes. 24 Male hearing-impaired volleyball players participated in the study. A health board report has been issued to volleyball players. Ethics committee approval has been granted.

\subsection{Training Schedule}

Both groups consisting of volunteers selected by the randomly and 3 days / 90 min. volleyball training programme was applied for two groups in a week. 20-minute warm-up exercises were applied to experimental and control groups. Both groups continued their practice volleyball training program. After warm up exercises, volleyball players of experimental group were trained plyometric training that was consisting of 20 different actions and lasted 30 minutes and had $80-100 \%$ exercise intensity. Resting time was made according to the full rest principle. The control group continued for their regular volleyball training. Then they were allowed to continue their volleyball practice. For the control group, normal volleyball training continued. The training time of the experiment and control group was the same.

Table 1. Movements used in plyometric studies

\begin{tabular}{llllll}
\hline 1. Jump Squat & 6. & Run Stance Squat & 11. High Knee & 16. Run Squat \\
2. Run stance Squat & 7. & Double Airborne Heisman & 12. Twist Combos & 17. Lateral Leap Frog \\
3. Airborne Heisman & 8. & Octagon & 13. Quick Feet Ladder & 18. Monster Truck Tire Leaps \\
4. Swing Bag & 9. & Lunge Jump & 14. Squat Jump & 19. Vertical Pike Jumping \\
5. Squat reach Back & 10. & Leap Frogs & 15. & Military March & 20. Stopping and Taking Three Steps \\
\hline
\end{tabular}

Table 2. Applied training schedule

\begin{tabular}{cclcc}
\hline Training days & Week & \multicolumn{1}{c}{ Drills } & Sets & \multicolumn{1}{c}{ Rest } \\
\hline $3 \times 2$ & $1-2$ & 2-Low intensity & $2 \times 10$ & $2 \times 30 \mathrm{sec}$ \\
$3 \times 2$ & $3-4$ & 2-Low, medium intensity & $2 \times 10$ & $2 \times 30 \mathrm{sec}$ \\
$3 \times 2$ & $5-6$ & 3-Medium intensity & $3 \times 10$ & $3 \times 30 \mathrm{sec}$. \\
$3 \times 2$ & $7-8$ & 4-High intensity & $4 \times 10$ & $5 \times 30 \mathrm{sec}$ \\
\hline
\end{tabular}




\section{Anthropometric Measurements and Tests}

In order to collect descriptive information in our study, the age of the subjects was identified asking them years of birth. Subjects were enrolled in anatomic condition, with sports clothes and without shoes, with a weight of $0.1 \mathrm{~kg}$ and a digital height scale (SECA, Germany) with a height in $\mathrm{cm}$ and a body weight in $\mathrm{kg}$ (Gordon et al., 1988).

\subsection{Height}

Stadiometre (SECA Germany) was used for height measurements with $0.01 \mathrm{~m}$ of accuracy degree in accordance with the measurement techniques (Gordon, 1988).

\subsection{Balance Measurement (Score)}

For the balance measurement, the Biodex Balance SD isokinetic balance device, previously validated by studies, was used. A test was administered to each participant and each test consisted of three measurements. A 10-second rest period was set between the tests. Both tests were performed on one foot, with the arms fixed on the sides and the other leg at 20 degrees flex. At the time of the static test, participant was asked to fix the point on the screen; it is desired to try to stabilize the fixed point against the maneuvering made to the front, back, right, left by keeping it within the specified area. Each measurement result was scored by the Biodex balance system (Cachupe, 2001)

\subsection{Data Analysis}

Statistical analysis was performed using SPSS 16.0 software package. Frequency and percentage distributions, mean and standard deviation, standard error are used as a Descriptive Statistics. Due to the fact that measurements of the groups showed normality and homogeneous distribution, Paired Samples T-Test was used for the significance between pre-test and post-test measurements. The Independent Samples T-Test was used to analyze the differences between the experimental group and the control group. The error level in this study was taken as $p$ $<0.05$

\section{Findings}

Table 3. Demographic information for hearing-impaired volleyball players of research groups

\begin{tabular}{lcc}
\hline \multirow{2}{*}{ Variables } & Experimental Group $(\mathrm{N}=12)$ & Control Group $(\mathrm{N}=12)$ \\
\cline { 2 - 3 } & Mean \pm S.D & Mean \pm S.D \\
\hline Age (year) & $19.08 \pm 1.62$ & $17.75 \pm 1.28$ \\
Height $(\mathrm{cm})$ & $177.50 \pm 5.07$ & $175.75 \pm 5.59$ \\
Weight $(\mathrm{kg})$ & $72.70 \pm 8.28$ & $59.11 \pm 9.71$ \\
\hline
\end{tabular}

The average age of the hearing impaired volleyball players in the experimental group was $19.08 \pm 1.62$ years, $177.50 \pm 5.07 \mathrm{~cm}$ in height, and $72.70 \pm 8.28 \mathrm{~kg}$ in average body weight. The average age of the hearing impaired volleyball players in the control group was $17.75 \pm 1.28$ years, their mean height values were $175.75 \pm 5.59 \mathrm{~cm}$ and the mean body weight values were $59.11 \pm 9.71 \mathrm{~kg}$. .

Table 4. Comparison of pretest and post-test static balance parameters of the experimental group

\begin{tabular}{|c|c|c|c|c|}
\hline \multirow{2}{*}{ Variables } & Pre Test (n: 15) & Post Test (n: 15$)$ & \multirow{2}{*}{$\mathrm{t}$} & \multirow{2}{*}{$\mathrm{P}$} \\
\hline & Mean \pm Sd & Mean \pm Sd & & \\
\hline Overall Stability-R & $1.69 \pm 0.61$ & $1.30 \pm 0.38$ & 2.933 & $0.014 *$ \\
\hline Anterior Posterior-R & $1.22 \pm 0.48$ & $1.00 \pm 0.34$ & 1.489 & 0.165 \\
\hline Medial Lateral-R & $0.99 \pm 0.34$ & $1.12 \pm 0.70$ & -0.773 & 0.456 \\
\hline Overall Stability-L & $1.80 \pm 0.83$ & $1.33 \pm 0.50$ & 3.561 & $0.004 *$ \\
\hline Anterior Posterior-L & $1.20 \pm 0.51$ & $0.91 \pm 0.39$ & 3.872 & $0.003 *$ \\
\hline Medial Lateral-L & $1.22 \pm 0.71$ & $0.85 \pm 0.41$ & 2.786 & $0.018^{*}$ \\
\hline
\end{tabular}

$\mathrm{p}<0.05$.

When the static balance parameters of the experimental group were analyzed, overall stability R, overall stability L and anterior posterior $\mathrm{L}$. values were found to be significant between the pretest and post-test $(\mathrm{p}<0.05)$. Anterior posterior $R$ and medial lateral $R$ values were not significant $(p>0.05)$. 
Table 5. Comparison of pretest and post-test static balance parameters of the control group

\begin{tabular}{|c|c|c|c|c|}
\hline Variables & $\begin{array}{c}\text { Pre Test (n: 15) } \\
\text { Mean } \pm \text { Sd }\end{array}$ & $\begin{array}{l}\text { Post Test (n: 15) } \\
\text { Mean } \pm \mathrm{Sd}\end{array}$ & $\mathrm{t}$ & $\mathrm{P}$ \\
\hline Overal Stability-R & $2.27 \pm 0.80$ & $2.30 \pm 0.80$ & -0.549 & 0.594 \\
\hline Anterior Posterior-R & $1.49 \pm 0.55$ & $1.24 \pm 0.78$ & 1.977 & 0.074 \\
\hline Medial Lateral-R & $1.54 \pm 0.67$ & $1.02 \pm 0.72$ & 2.812 & $0.017^{*}$ \\
\hline Overall Stability-L & $2.25 \pm 0.90$ & $2.18 \pm 0.65$ & 0.744 & 0.473 \\
\hline Anterior Posterior-L & $1.51 \pm 0.70$ & $1.35 \pm 0.56$ & 0.856 & 0.410 \\
\hline Medial Lateral-L & $1.31 \pm 0.59$ & $1.10 \pm 0.57$ & 1.727 & 0.112 \\
\hline
\end{tabular}

$\mathrm{p}<0.05$.

When the static balance parameters of the control group were analyzed, medial lateral $\mathrm{R}$ value was found to be significant between pretest and post-test $(\mathrm{p}<0.05)$. Overall stability $\mathrm{R}$, overall stability $\mathrm{L}$, anterior posterior $\mathrm{L}$, anterior posterior $\mathrm{R}$ and medial lateral $\mathrm{L}$ values were not significant $(\mathrm{p}>0.05)$.

Table 6. Comparison of the pretest and post-test differences of static balance measurement parameters for the experimental and control group of hearing impaired volleyball players

\begin{tabular}{|c|c|c|c|c|}
\hline Variables & & Mean \pm SD & $\mathrm{t}$ & $\mathrm{P}$ \\
\hline \multirow{2}{*}{ Overall Stability- R } & Experimental Group & $0.39 \pm 0.46$ & \multirow{2}{*}{2.897} & \multirow{2}{*}{$0.008 *$} \\
\hline & Control Group & $-0.03 \pm 0.21$ & & \\
\hline \multirow{2}{*}{ Anterior Posterior- $\mathrm{R}$} & Experimental Group & $0.21 \pm 0.50$ & \multirow{2}{*}{-0.173} & \multirow{2}{*}{0.864} \\
\hline & Control Group & $0.25 \pm 0.43$ & & \\
\hline \multirow{2}{*}{ Medial Lateral-R } & Experimental Group & $-0.13 \pm 0.59$ & \multirow{2}{*}{-2.579} & \multirow{2}{*}{$0.017^{*}$} \\
\hline & Control Group & $0.51 \pm 0.63$ & & \\
\hline \multirow{2}{*}{ Overall Stability-L } & Experimental Group & $0.46 \pm 0.45$ & \multirow{2}{*}{2.369} & \multirow{2}{*}{$0.027 *$} \\
\hline & Control Group & $0.07 \pm 0.34$ & & \\
\hline \multirow{2}{*}{ Anterior Posterior-L } & Experimental Group & $0.29 \pm 0.26$ & \multirow{2}{*}{0.599} & \multirow{2}{*}{0.556} \\
\hline & Control Group & $0.16 \pm 0.67$ & & \\
\hline \multirow{2}{*}{ Medial Lateral-L } & Experimental Group & $0.36 \pm 0.45$ & \multirow{2}{*}{0.825} & \multirow{2}{*}{0.418} \\
\hline & Control Group & $0.21 \pm 0.43$ & & \\
\hline
\end{tabular}

$\mathrm{p}<0.05$.

For the experimental and control groups, statistical significance was found in the values of overall stability R, medial lateral $\mathrm{R}$, and overall stability $\mathrm{L}$ in comparing the mean values of the pretest values and the post-test values of the static balance measurement parameters $(p<0.05)$. Anterior posterior R. anterior posterior $\mathrm{L}$. medial lateral $\mathrm{L}$. mean values were not significantly different $(\mathrm{p}>0.05)$

\section{Discussion}

In this study, the effects of plyometric training on hearing impaired volleyball players during eight weeks were investigated.

Experimental and control group of hearing-impaired sportsmen participating in the study; body weight, height, and balance were included in the results by comparing the pre-test and post-test physical parameters.

The average age of the hearing impaired volleyball players in the experimental group was $19.08 \pm 1.62$ years, $177.50 \pm 5.07 \mathrm{~cm}$ in height, and $72.70 \pm 8.28 \mathrm{~kg}$ in average body weight. The average age of the hearing impaired volleyball players in the control group was $17.75 \pm 1.28$ years, their mean height values were $175.75 \pm 5.59 \mathrm{~cm}$ and the mean body weight values were $59.11 \pm 9.71 \mathrm{~kg}$.

Açak et al. (2012) found that the average body weight in hearing-impaired athletes who had never heard was 74.2 $\mathrm{kg}$., for hearing-impaired athletes who can hear with headphones $74.4 \mathrm{~kg}$. It is seen that the average body weight is close to our study.

Yörükoğlu and Koz (2007) reported that age and anthropometric measurements of children had an impact on the development of sportive performance.

Eylen et al. (2017) reported that the working capacities of intramuscular and intramuscular muscle groups are 
increased due to the increase in muscle strength by various strength training.

Plyometric exercises are one of the most commonly used training models for supporting strength development and shortening the strength level. Plyometric training also contributes to the development of physical performance (Piirainen et al., 2011).

Plyometric exercises are known as drills by coaches. These twirls have been combined to improve speed of movement and force-power production. Plyometric training is now being used in many sport branches that require quick power (Takahashi, 1992).

Gheysen et al. (2007) stated that hearing impaired children may be late in motor development; lack of regular and coordinated muscle activities due to the lack of auditory stimulation may cause these children to have weak muscle strength.

When the static balance parameters of the experimental group were examined, overall stability R, overall stability $\mathrm{L}$ and anterior posterior $\mathrm{L}$. values were found to be significant between the pretest and post-test $(\mathrm{p}<0.05)$. Anterior posterior $R$ and medial lateral $R$ values were not significant $(\mathrm{p}>0.05)$.

When the static balance parameters of the control group were examined, medial lateral $\mathrm{R}$ value was found to be significant between pretest and post-test $(\mathrm{p}<0.05)$. Overall stability $\mathrm{R}$, overall stability $\mathrm{L}$, anterior posterior $\mathrm{L}$, anterior posterior $\mathrm{R}$ and medial lateral $\mathrm{L}$ values were not significant $\mathrm{p}>0.05$ ).

For the experimental and control groups, statistical significance was found in the values of overall stability R, medial lateral $\mathrm{R}$, and overall stability $\mathrm{L}$ in comparing the mean values of the pretest values and the post-test values of the static balance measurement parameters $(\mathrm{p}<0.05)$. Anterior posterior $\mathrm{R}$. anterior posterior $\mathrm{L}$. medial lateral L. mean values were not significantly different $(\mathrm{p}>0.05)$.

Karakoç (2014) stated that in the research, the continuously applied coordination and balance exercises increased the performances of hearing-impaired athletes and dynamic balance exercises and static balance exercises affected the performance positively.

Gür and Ersöz (2017) found that static balance parameters decreased to $16.50 \pm 7.39 \mathrm{~mm} / \mathrm{s}$ before forth and back speed training and $15.40 \pm 7.08 \mathrm{~mm} / \mathrm{s}$ after training $(\mathrm{p}>0.05)$. In the control group, the mean back and forth speed increased to $19.66 \pm 7.96 \mathrm{~mm} / \mathrm{s}$ before training and $20.77 \pm 8.36 \mathrm{~mm} / \mathrm{s}$ after training $(\mathrm{p}>0.05)$.

Kurt A. worked with 15 active hearing-impaired athletes aged 16-19 years and 15 sedater of hearing impaired and found that the hearing impaired athletes who do sports have better balance skills than the sedater of hearing impairments children and stated that regular training has a positive effect on balance (Kurt, A. 2007).

Sharma et al. (2012) found that there was no significant improvement on balance performance of 9 week core training applied to active volleyball players.

Taskin et al (2015) stated that in the research, volleyball is expected to be good due to the static balancing features of the game.

Yagci et al. (2004) studied on normally developing athletes and hearing-impaired athletes, and found a meaningful level $(p<0.001)$ in the balance ability of the group consisting of the normally developing athletes, the least significant level in the group of hearing-impaired athletes.

Holm et al. (2004) found that 8 -week neuromuscular exercise programs were significant in the dynamic balance results of female handball players.

Sundberg (1982) compared the balance periods of visually impaired individuals and the non-visually impaired individuals who were of similar age and gender, when statistical results were examined; it was found that there were significant differences in favor of non-visually impaired individuals who participated in the study.

Khidr (2010) found that supporting judo teaching has positive effects on learning and balance skills of hearing-impaired athletes.

İnanır et al. (2013) found in the study on the evaluation of postural balance and fall risk in patients with rheumatoid arthritis, the mean and standard deviation values of healthy subjects with a mean age of $42.97 \pm 9.12$ were $0.54 \pm$ 0.40 , the mean anterior-posterior balance and standard deviation values were $0.42 \pm 0.29$, lateral balance averages and standard deviation values were found as $0.28 \pm 0.25$.

Sağıroğlu (2008) formed a group that was doing plyometric training for 3 days a week and a group that was doing Pliometer training for 1 day a week for 8 weeks and found no significance at $p>0.05$ level in terms of balance scores. 
Balance tests can also be performed on one and two feet on different platforms, with the eyes open and closed (Fleck et al., 1985). When we look at the similar studies in the literature; it is seen that the general balance scores in our study were lower than some of the other studies, higher than some, and parallel to some of them. It can be assumed that these differences are due to the different balance devices being measured, the diversity of the software and the different calculation of data. In addition, differences in the training programs are thought to be related to their duration of implementation. Changes in the systems may also differ in the measured balance methods.

\section{Conclusion}

As a result; it is thought that there is a positive development in balance characteristics of hearing-impaired volleyball players with regular plyometric training. It can be said that the application of plyometric training in addition to the volleyball training is beneficial in terms of sporting performance.

It is thought that the plyometric training can be applied to the athletes of other branches as well as to the volleyball players.

\section{Acknowledgements}

This is a part of Ersin Nacaroglu's master thesis. We thank our department of Physical Education and Sport in University of Gaziantep for their support to our study.

\section{References}

Açak, M., Karademir, T., Taşmektepligil, Y., \& Çalışkan, E. (2012). İşitme Engelli Futsal Sporcularının Çeviklik ve Görsel Reaksiyon Zamanının Karşılaştııılması. Selçuk Üniversitesi Beden Eğitimi ve Spor Bilimleri Dergisi, 14(2), 283-289.

Butterfield, S. A. (1991). Influence of age, sex, hearing loss, and balance on development of running by deaf children. Perceptual and motor skills, 73(2), 624-626. https://doi.org/10.2466/pms.1991.73.2.624

Cachupe, W. J., Shifflett, B., Kahanov, L., \& Wughalter, E. H. (2001). Reliability of biodex balance system measures. Measurement in physical education and exercise science, 5(2), 97-108. https://doi.org/10.1207/s15327841mpee0502_3

Eylen, M. A., Daglioglu, O., \& Gucenmez, E. (2017). The Effects of Different Strength Training on Static and Dynamic Balance Ability of Volleyball Players. Journal of Education and Training Studies, 5(13), 13. https://doi.org/10.11114/jets.v5i13.2881

Fleck, S. J., Case, S., Puhl, J., \& Van Handle, P. (1985). Physical and physiological characteristics of elite women volleyball players. Canadian journal of applied sport sciences. Journal canadien des sciences appliquees au sport, 10(3), 122-126.

Gheysen, F., Loots, G., \& Van Waelvelde, H. (2007). Motor development of deaf children with and without cochlear implants. Journal of Deaf Studies and Deaf Education, 13(2), 215-224. https://doi.org/10.1093/deafed/enm053

Gordon, C. C., Chumlea, W. C., \& Roche, A. F. (1988). Stature, recumbent length, and weight. Anthropometric standardization reference manual. Champaign: Human kinetics Books (pp. 3-8).

Gür, F., \& Ersöz, G. (2017). Kor Antrenmanın 8-14 Yaş Grubu Tenis Sporcularının Kor Kuvveti. Statik Ve Dinamik Denge Özellikleri Üzerindeki Etkisinin Değerlendirilmesi.

Holm, I., Fosdahl, M. A., Friis, A., Risberg, M. A., Myklebust, G., \& Steen, H. (2004). Effect of neuromuscular training on proprioception, balance, muscle strength, and lower limb function in female team handball $\begin{array}{lllll}\text { players. } \quad \text { Clinical Journal of Sport } & \text { Medicine, } & \text { 14(2), } & \text { 88-94. }\end{array}$ https://doi.org/10.1097/00042752-200403000-00006

Inanir, A., Okan, S., \& Yildirim, E. (2013). Romatoid Artritte Postural Denge ve Dusme Riski. Cukurova Medical Journal, 38(1), 1. https://doi.org/10.5455/cutf.27409

Karakoc, O. (2014). İşitme Engelli Judocularda Sekiz Haftalık Denge Ve Koordinasyon Antrenmanlarının Performans Üzerine Etkileri. Yayınlanmış Doktora Tezi. Fırat Üniversitesi, Sağlık Bilimleri Enstitüsü Beden Eğitimi ve Spor Anabilimdalı.

Khidr, F. A. M. (2010). Effect of using modern soft program for learning some judo skills and lonely feeling to the Hearing Impaired People. Procedia-Social and Behavioral Sciences, 5, 2058-2062. https://doi.org/10.1016/j.sbspro.2010.07.412 
Kurt, A. (2007). Düzenli Egzersizin İsitme Engelli ve Normal Bireylerde Denge Parametreleri Üzerine Etkisi. Yayınlanmamış Yüksek Lisans Tezi. Erciyes Üniversitesi, Sağlık Bilimleri Enstitüsü, Beden Eğitimi ve Spor Anabilim Dalı. Kayseri.

Piirainen, J. M., Cronin, N. J., Avela, J., \& Linnamo, V. (2014). Effects of plyometric and pneumatic explosive strength training on neuromuscular function and dynamic balance control in 60-70year old males. Journal of Electromyography and Kinesiology, 24(2), 246-252. https://doi.org/10.1016/j.jelekin.2014.01.010

Riemann, B. L., \& Lephart, S. M. (2002). The sensorimotor system, part II: the role of proprioception in motor control and functional joint stability. Journal of athletic training, 37(1), 80.

Sağıroğlu, İ. (2008). Genç basketbolcularda pliyometrik antrenmanların anaerobik performans ve dikey sıçrama yüksekliğine etkisi (Doctoral dissertation, DEÜ Sağlık Bilimleri Enstitüsü).

Sandrey, M. A. (2006). The comparative effects of a six-week balance training program. Gluteus medius strength training program and combined balance training/gluteus medius strength training program on dynamic postural control. Master of Science in athletic training. School of Physical Education. Morgantown. West Virginia.

Sharma, A., Geovinson, S. G., \& Singh, S. J. (2012). Effects of a nine-week core strengthening exercise program on vertical jump performances and static balance in volleyball players with trunk instability. The Journal of sports medicine and physical fitness, 52(6), 606-615.

Sundberg, S. (1982). Maximal oxygen uptake in relation to age in blind and normal boys and girls. Acta Paediatrica, 71(4), 603-608. https://doi.org/10.1111/j.1651-2227.1982.tb09482.x

Takahashi, R. (1992). Plyometrıcs: Power training for judo: Plyometric training with medicine balls. Strength \& conditioning Journal, 14(2), 66-71. https://doi.org/10.1519/0744-0049(1992)014<0066:PTFJPT>2.3.CO;2

Taşkın, C.,Karakoç Ö,Yüksek S.(2015) İşitme Engelli Voleybol ve Hentbol Erkek Sporcuların Statik Denge Performans Durumlarının İncelenmesi. The Journal of Academic Social Sciences, 17(17), 248. https://doi.org/10.16992/asos.831

Yağcı, N., Cavlak, U., \& Şahin, G. (2004). İşitme Engellilerde Denge Yeteneğinin İncelenmesi Üzerine Bir Çalışma. KBB-Forum 2004, 3(2).

Yörükoğlu, U., \& Koz, M. (2007). Spor Okulu Çalışmaları İle Basketbol Antrenmanlarının 10-13 Yaş Grubu Erkek Çocukların Fiziksel. Fizyolojik Ve Antropometrik Özelliklerine Etkisi, Spormetre Beden Eğitimi ve Spor Bilimleri Dergisi, 2, 79-83. https://doi.org/10.1501/sporm_0000000075

\section{Copyrights}

Copyright for this article is retained by the author(s), with first publication rights granted to the journal.

This is an open-access article distributed under the terms and conditions of the Creative Commons Attribution license (http://creativecommons.org/licenses/by/4.0/). 